\title{
ANALISIS MODEL-MODEL PEMBELAJARAN
}

\author{
Putri Khoerunnisa \& Syifa Masyhuril Aqwal \\ Universitas Muhammadiyah Tangerang \\ khoerunnisaputri20@gmail.com, syifaquril10@gmail.com
}

\begin{abstract}
This study aims to how to understand teaching models. And to find out what are the main models of teaching. Teaching models in a sense are seen as more prominent and relevant to the guidance of the world education needs of the world today. Modification, especially to some teaching methods, compilation do it fully in the framework of developing or adjusting to the needs. As prospective teachers and professional teachers are also expected to make adjustments as necessary to the model if it is necessary to match the teaching-learning context which may be different from what is compiling in this section. Learning design is practice the formulation of communication and media technology media to help effectively transfer knowledge between teachers and students. Learning design is also a design of the learning process based on the needs and learning objectives and delivery system so that it becomes a reference in its implementation to create effective and efficient learning by minimizing the difficulty of students in understanding learning. On the personal development of students by paying more attention to the realm of sense, especially in emotional.the help of the personal model family is more emphasized on the formation and organization of the reality of environmental life and unique life. Hopefully, using this learning model the process of teaching and learning can help students develop their own productive relationships with their environment. Students as students can also realize themselves himself as a "person" with sufficient skills to interact with outsiders so as to produce a pattern of conducive interpersonal relationships.
\end{abstract}

Keywords : Teacher, Instructional, Learning Model

\begin{abstract}
Abstrak: Penelitian ini bertujuan untuk bagaimana cara memahami model-model pengajaran.dan untuk mengetahui apa saja model pokok mengajar.Model-model mengajar dalam arti dipandang lebih menonjol dan relevan dengan tuntunan kebutuhan dunia Pendidikan dunia masa kini.Modifikasi,khususnya terhadap sebagian metode mengajar,penyusunan lakukan sepenuhnya dalam rangka pengembangan atau penyesuaian dengan kebutuhan.Kepada selaku calon guru dan guru profesional juga diharapkan melakukan penyesuaian seperlunya terhadap model tersebut apabila dirasa perlu untuk menccokkan dengan konteks mengajar-belajar yang mungkin berbeda dengan apa yang penyusun pada bagian ini.Desain pembelajaran adalah praktek penyusunan media teknologi komunikasi da nisi untuk membantu agar dapat terjadi transfer pengetahuan secara efektif antara guru dan peserta didik. Desain pembelajaran juga merupakan rancangan atas proses pembelajaran berdasarkan kebutuhan dan tujuan belajar serta system penyampaiannya sehingga menjadi acuan dalam pelaksanaannya untuk menciptakan pembelajaran yang efektif dan efisien dengan meminimalisir kesukaran siswa dalam memahami pembelajaran.Pada pengembangan pribadi siswa dengan lebih banyak memerhatikan kehidupan ranah rasa,terutama sisi emosionalnya.bantuan rumpun model personal lebih ditekankan pada perbentukkan dan pengorganisasiaan realitaskehidupan lingkungan dan kehidupan yang unik.Diaharapkan,dengan menggunakan model pembelajaran ini proses menagajar-belajar dapat menolong siswa dalam mengembangkan sendiri hubungan yang produktif dengan
\end{abstract}

Fondatia : Jurnal Pendidikan Dasar

Volume 4, Nomor 1, Maret 2020; 1-27

https://ejournal.stitpn.ac.id/index.php/fondatia 
lingkungannya.Siswa sebagai peserta didik juga dapat menyadari dirinya sendiri sebagai seorang "pribadi" yang berkecakapan cukup untuk berinteraksi dengan pihak luar sehingga menghasilkan pola hubungan interpersonal yang kondusif.

Kata Kunci : Guru, Intruksional, Model Pembelajaran

\section{PENDAHULUAN}

Dalam menyusun sebuah desain pembelajaran, konsep interaksi merupakan sesuatu yang cukup penting untuk diperhitungkan. Oleh karena itu desain pembelajaran tidak dapat digantikan dengan desain informasi. Interaksi sangat berkaitan dengan keberagaman peserta didik. Hal inilah yang menuntut designer pembelajaran untuk dapat memunculkan bermacam-macam desain-desain pembelajaran yang bervariasi

Model-model pembelajaran sendiri biasanya disusun berdasarkan berbagai prinsip atau teori pengetahuan.Para ahli menyusun model pembelajaran berdasarkan berbagai prinsip atau teori pengetahuan. Para ahli menyusun model pembelajaran berdasarkan prinsip-prinsip pembelajaran, teori-teori psikologis, sosiologis, analisis sistem, atau teori-teori yang lain yang mendukung. Joyce \& Weil mempelajari modelmodel berdasarkan teori belajar yang dikelompokan menjadi empat model pembelajaran. Model tersebut merupakan Pola Umum perilaku pembelajaran untuk mencapai tujuan pembelajaran yang diharpkan. Joyce \& Weil berpendapat bahwa model pembelajaran adalah suatu rencana atau pola yang dapat digunakan untuk membentuk kurikulum (rencana pembelajaran jangka panjang), merancang bahanbahan pembelajaran, dan membimbing pembelajaran di kelas atau yang lain. Model pembelajaran dapat dijadikan pola pilihan, artinya para guru memilih model pembelajaran yang sesuai dan efisien untuk mencapai tujuan pendidikannya.

\section{Pengertian Model Pembelajaran}

Strategi menurut Kemp (1995) adalah suatu kegiatan pembelajaran yang harus dikerjakan guru dan siswa agar tujuan pembelajaran dapat dicapai secara efektif dan efisien.Senada dengan pendapatnya Kemp, Dick and Carey (1985) juga menyebutkan bahwa strategi pembelajaran adalah sutau perangkat materi dan prosedur pembelajaran yang digunakan secara bersama-sama untuk menimbulkan hasil belajar 
pada peserta didik atau siswa. ${ }^{1}$ Upaya mengimplementasikan rencana pembelajaran yang telah di susun dalam kegiatan nyata agar tujuan yang telah disusun dapat tercapai secara optimal, maka diperlukan suatu metode yang digunakan untuk merealisasikan strategi yang telah ditetapkan.Dengan demikian, bisa terjadi satu strategi pembelajaran menggunakan beberapa metode.

Model-model pembelajaran sendiri biasanya disusun berdasarkan berbagai prinsip atau teori pengetahuan.Para ahli menyusun model pembelajaran berdasarkan berbagai prinsip atau teori pengetahuan. Para ahli menyusun model pembelajaran berdasarkan prinsip-prinsip pembelajaran, teori-teori psikologis, sosiologis, analisis sistem, atau teori-teori yang lain yang mendukung. ${ }^{2}$ Joyce \& Weil mempelajari modelmodel berdasarkan teori belajar yang dikelompokan menjadi empat model pembelajaran. Model tersebut merupakan Pola Umum perilaku pembelajaran untuk mencapai tujuan pembelajaran yang diharapkan. Joyce \& Weil berpendapat bahwa model pembelajaran adalah suatu rencana atau pola yang dapat digunakan untuk membentuk kurikulum (rencana pembelajaran jangka panjang), merancang bahanbahan pembelajaran, dan membimbing pembelajaran di kelas atau yang lain. Model pembelajaran dapat dijadikan pola pilihan, artinya para guru memilih model pembelajaran yang sesuai dan efisien untuk mencapai tujuan pendidikannya.

\section{Model-model Pengajaran}

Teori yang tampaknya kuno, sekaligus bersifat umum, tidak rumit, ditulis DeQueljoe dan A. Gazalli dalam buku mereka Diktaktik Umum.Dalam buku itu mereka menggunakan istilah jalan pelajaran sebagai padanan istilah model pengajaran.Ada empat jalan pelajaran yang mereka tulis dalam buku itu (De Queljoe dan Gazalli, 1962:94-101).

1. Jalan Pelajaran Konsentris

Pada jalan pelajaran ini seluruh bahan pelajaran dijalani beberapa kali dan permulaan hingga akhir, dimulai dari yang paling mudah dan paling penting.

\footnotetext{
1 Syah, Muhibbin. 2010. Psikologis Pendidikan. Bandung : PT Remaja Rosdakarya. 2 Jamaluddin, Dindin. 2010. Metode Pendidikan Anak. Bandung : Pustaka Al-Fikriis. Jurnal Saintech Vol. 08 - No.04-Desember 2016.
} 
2. Jalan Pelajaran Suksesstif

Suksessi artinya urutan atau berurutan.Di dalam jalan pelajaran ini seluruh bahan hanya dilalui satu kali, karena pengajaran maju secara berurutan.

3. Jalan Pelajaran Sintensis

Jalan pelajaran ini menunjukan kegiatan belajar-mengajar seharusnya dimulai dari mempelajari unsur-unsur atau bagian-bagian untuk selanjutnya membuat kesimpulan atau merumuskan keseluruhan. Dalam pengajaran membaca misalnya, jalan pengajaran ini akan dilakukan dengan memulai proses pengajaran dengan mengenali huruf-huruf, lalu suku kata, lanta kata, kalimat untuk selanjutnya cerita.

4. Jalan Pelajaran Analisis

Jalan pelajaran ini merupakan kebalikan jalan pelajaran sintensis.Dimulai dari yang umum, menuju yang khusus; dari kebutuhan menuju bagian-bagian. Prinsip yang mendasarinya ialah model deduktif

Keempat jalan pelajaran (atau jalan pengajaran) di atas masih dapat digunakan sampai sekarang, sekurang-kurangnya dapat dijadikan model teoritis.

\section{Model dan Metode Pokok Mengajar}

Modifikasi, khususnya terhadap sebagian metode mengajar, lakukan seperlunya dalam rangka pengembangan atau penyesuaian dengan kebutuhan. Kepada selaku calon guru dan guru professional juga diharapkan melakukan penyesuaian seperlunya terhadap model dan metode tersebut apabila dirasa perlu untuk mencocokan dengan konteks mengajar-belajar yang mungkin berada dengan apa yang diuraikan pada bagian ini.

Model -model mengajar (teaching models) adalah blue print mengajar yang direkayasa sedemikian rupa untuk mencapai tujuan-tujuan tertentu pengajaran. Cetak biru (blue print) ini lazimnya dijadikan pedoman perencanaan dan pelaksanaan pengajaran serta evaluasi belajar.

Kumpulan atau set model mengajar yang dianggap komperhensif menurut Tardit(1989) adalah set model yang dikembangkan oleh Bruce Joyce dan Marsha Weil 
dengan kategorisasi sebagai berikut: 1) model information processing 2) model personal 3) model social 4) model behavioral. ${ }^{3}$

1. Model Information Processing (Tahapan Pengolahan Informasi)

Information Processing adalah sebuah istilah kunci dalam psikologis kognitif yang akhir-akhir ini semakin mendominasi sebagian besar upaya riset dan pembahasan psikologis pendidikan. Information processing sebagai sebuah rumpun model-model mengajar perlu dipelajari dan diterapkan sebaik-baiknya dalam proses belajar mengajar agar ranah cipta siwa dapat berkembang dan berfungsi seoptimal mungkin. Pengembangan ranah cipta dalam proses belajar mengajar dipandang vital dan strategis, karena ranah kejiwaan yang paling dominan adalah ranah cipta (kognitif).

Model Peningkatan Kapasitas Berpikir

Diantara model-model mengajar yang termasuk kategori Information processing adalah Model Peningkatan Kapasitas Berpikir yang diilhami oleh metode klinis ciptaan Jean Piaget (1896-1980).Penerapan Model Peningkatan Kapasitas Berpikir diarahkan pada pengembangan-pengembangan sebagai berikut.

a. Daya cipta akal siswa

b. Berpikir kritis siswa

c. Penilaian mandiri siswa dan juga pengembangan.

d. Sosio-emosional siswa (perasaan kemasyarakatan) sebagai sudah satu fenomena ranah rasa siwa.

2. Model Personal (Pengembangan Pribadi)

Rumpunan model personal pada umumnya berorientasi pada pengembangan pribadi siswa dengan lebih banyak memperhatikan kehidupan ranah rasa, terutama fungsi emosionalnya.Siswa peserta didik juga dapat menyadari dirinya sendiri sebagai seorang "pribadi" yang berkecakapan cukup untuk berintrekasi dengan pihak luar sehingga menghasilkan pola hubungan interpersonal yang kondusif.

3Jamaluddin, Dindin. 2010. Metode Pendidikan Anak. Bandung: Pustaka Al-Fikriis. Jurnal Saintech Vol. 08 - No.04-Desember 2016. 


\section{Model nondirektif}

Di antara sekian banyak model yang termasuk kategori model nondirektif. Model ini pada umunya dirancang secara sederhana untuk membantu mempermudah proses belajar pada siswa secara umum, dalam arti tidak ditunjukan pada aktivitas belajar materi tertentu. Teknik yang lazim digunakan untuk mengidentifikasikan model nondirektif adalah teknik wawancara.

3. Model Social (Hubungan Bermasyarakat)

Model social adalah rumpun model mengajar yang menitikberatkan pada proses interaksi antarindividu yang terjadi dalam kelompok individu tersebut. Sesuai dengan penekanan atau peniktikberatnnya, aplikasi rumpun model sosial diprioritaskna untuk mengembangkan kecakapan individu siswa dalam berhubungan dengan orang lain atau masyarakat disekitarnya. ${ }^{4}$

Model Role Playing (Bermain Peran)

Selaku calon guru atau guru professional, diharapkan kreatif dalam mencari pendekatan-pendekatan mengajar yang lebih maju dalam memecahkan masalah atau mengefisienkan proses belajar para siswanya. Pendekatan yang maju maksudkannya, pendekatan yang selaras dengan kebutuhan kependidikan masa kini yang sudah tentu berbeda dengan tuntunan masyarakat terhadap pendidikan pada masa lampau.

4. Model Behavioral (Pengembangan Perilaku)

Rumpunan model mengajar perkembangan perilaku direkayasa atas dasar kerangka teori perilaku yang dihubungkan dengan proses belajar dan mengajar. Aktivitas mengajar, menurut teori ini harus ditujukan pada timbulnya perilaku bau atau berubahanya perilaku siswa ke arah yang sejalan dengan harapan.

Rumpunan model mengajar behavioral banyak dilandasi oleh asumsi empiris bahwa segenap perilaku siswa adalah fenomena yang dapat diobservasi, diukur, dan dijabarkan dalam bentuk perilaku-perilaku khusus, perilaku-perilaku khusus inilah yang menjadi tujuan belajar siswa.

Model mastery learning (belajar tuntas)

${ }^{4}$ Syah, Muhibbin. 2010. Psikologis Pendidikan. Bandung : PT Remaja Rosdakarya. 
Model mengajar mastery learning, yang dalam istilah Benjamin Bloom disebut learning for mastery itu pada dasarnya merupakan pendekatan mengajar yang mengacu pada penetapan kriteria hasil belajar. Pengajaran dengan model mastery learning dapat dilaksanakan, baik secara individual maupun secara individual, meskipun relatif lebih sulit, guru dapat mengapalikasikannya dalam konteks pengajaran kelas dengan memberi perlakuan-perlakuan khusus terhadap siswa tertentu.

\section{Model Pembelajaran Berdasarkan Teori}

1. Model Interaksi Sosial

Model ini didasari oleh teori belajar Gestalt (field theory).Model Interaksi Sosial menitikberatkan hubungan yang harmonis antara individu dengan masyarakat (learning to life togerher).Teori Pembelajaran Geaslt dirintis oleh Max Wertheimer (1912) Bersama dengan Kurt Koffka dan W.kohler, mengadakan eksperimen mengenai pengamatan visual dengan fenomena fisik.Percobaannya, yaitu memproyeksikan titik-titik cahaya (keseluruhanlebih penting daripada bagian). ${ }^{5}$

Pokok pandangan Gesalt adalah objek atau peristiwa tertentu akan dipandang sebagai suatu keseluruhan yang terorganisasikan. Makna suatu objek/peristiwa adalah terletak pada keseluruhan bentuk (gestalt) dan bukan bagian-bagiannya. Pembelajaran akan lebih bermakna bila materi diberikan secara utuh, bukan bagian-bagian.

Aplikasi Teori Gestalt dalam Pembelajaran adalah:

a. Pengalaman (insight/tilikan). Dalam proses Pembelajaran siswa hendaknya memliki kemampuan insight, yaitu kemampuan mengenal keterkaitan unsurunsur dalam suatu objek. Guru hendaknya mengembangkan kemampuan siswa dalam memecahkan masalah dengan insight.

b. Pembelajaran yang bermakna. Kebermaknaan unsur-unsur yang terkait dalam suatu objek akan menunjang pembentukan pemahaman dalam proses

${ }^{5}$ Rusman. 2010. Model-model Pembelajaran. Jakarta: PT RajaGrafindo Persada 
pembelajaran. Content yang dipelajari siswa hendaknya memliki makna yang jelas baik bagi dirinya maupun bagi kehidupan di masa yang akan datang.

c. Perilaku bertujuan. Perilaku terarah pada suatu tujuan. Perilaku di samping adanya kaitan dengan SR-bond, juga terkait erat dengan tujuan yang hendak dicapai. Pembelajaran akan berhasil bila siswa mengetahui tujuan yang akan di capai.

d. Prinsip ruang hidup (life space). Dikembangkan oleh Kurt Lewin ( terori medan/field theory). Perilaku siswa terkait dengan lingkungan/ medan dimana ia berada. Materi yang disampaikan hendaknya memliki kaitan dengan situasi lingkungan dimana siswa berada (kontekstual). ${ }^{6}$

Model Interkasi Sosial ini mencakup strategi pembelajaran sebagai berikut.

a. Kerja kelompok, bertujuan mengembangkan keterampilan berperan serta dalam proses bermasyarakat dengan cara mengembangkan hubungan interpersonal dan discovery skills dalam bidang akademik.

b. Pertemuan kelas, bertujuan untuk mengembangkan pemahaman mengenai diri sendiri dan rasa tanggung jawab baik terhadapa diri sendiri maupun terhadap orang kelompok.

c. Pemecahan masalah social atau Social Inquiry, bertujuan untuk mengembangkan kemampuan memecahkan masalah-masalah social dengan cara berpikir logis.

d. Bermain Peranan, bertujuan untuk memberikan kesempatan kepada peserta didik menemukan nilai-nilai social dan pribadi melalui situasi tiruan.

e. Simulasi social, bertujuan untuk membantu siswa mengalami berbagai kenyataan social serta menguji reaksi mereka.

\begin{tabular}{|c|l|l|l|}
\hline No & \multicolumn{1}{|c|}{ Model } & \multicolumn{1}{c|}{ Tokoh } & \multicolumn{1}{c|}{ Tujuan } \\
\hline 1 & Penentuan & Herbert Telen \& & Perkembangan keterampilan untuk pertisipasi \\
& kelompok & John Dewey & dalam proses social demokratis melalui \\
& & & penekanan yang dikombinasikan pada \\
& & & keterampilan-keterampilan antar pribadi \\
& & & (kelompok) dan keterampilan-keterampilan \\
\hline
\end{tabular}

${ }^{6}$ Prisansa, Donni Juni. 2016. Pengembangan Strategi Dan Model Pembelajaran. Bandung : CV Pustaka Setia 


\begin{tabular}{|c|l|l|l|}
\hline & & & $\begin{array}{l}\text { penentuan akademik. Aspek perkembangan } \\
\text { pribadi merupakan hal yang peting dalam model } \\
\text { ini. }\end{array}$ \\
\hline 2 & Inkuiri Sosial & $\begin{array}{l}\text { Byron Massialas \& } \\
\text { Benjamin Cox }\end{array}$ & $\begin{array}{l}\text { Pemecahan masalah social, terutama melalui } \\
\text { penemuan social dan penalaran logis. }\end{array}$ \\
\hline 3 & $\begin{array}{l}\text { Metode } \\
\text { laboratory }\end{array}$ & $\begin{array}{l}\text { Bethel Maine } \\
\text { National Teaching } \\
\text { Library) }\end{array}$ & $\begin{array}{l}\text { Perkembangan keterampilan antar pribadi dan } \\
\text { kelompok melalui kesadaran dan keluwesan } \\
\text { pribadi. }\end{array}$ \\
\hline 4 & Jurisprudensial & $\begin{array}{l}\text { Donald Oliver \& } \\
\text { James P. Shaver }\end{array}$ & $\begin{array}{l}\text { Dirancang terutama untuk mengajarkan kerangka } \\
\text { acuan yurisprudensial sebagai cara berpikir dan } \\
\text { penyelesaian isu-isu social. }\end{array}$ \\
\hline 5 & Bermain Peran & $\begin{array}{l}\text { Fainnie Shatel } \\
\text { \&George Fhatel }\end{array}$ & $\begin{array}{l}\text { Dirancang untuk memengaruhi siswa agar } \\
\text { menemukan nilai-nilai pribadi dan social. Perilaku } \\
\text { dan nilai-nilai diharapkan siswa menjadi sumber } \\
\text { bagi penemuan berikutnya. }\end{array}$ \\
\hline 6 & Simulasi Sosial & $\begin{array}{l}\text { Sarane Bookock \& } \\
\text { Harold Guetzkov }\end{array}$ & $\begin{array}{l}\text { Dirancang untuk mambantu siswa mengalami } \\
\text { bermacam-macam proses dan kenyataan social, } \\
\text { dan untuk menguji reaksi siswa, serta untuk } \\
\text { memperoleh konsep keterampilan pembuatan } \\
\text { keputusan. }\end{array}$ \\
\hline
\end{tabular}

\section{Model Pemrosesan Informasi}

Model ini berdasarkan teori belajar kognitif ( Piaget) dan berorientasi pada kemampuan siswa memproses informasi yang dapat memperbaiki kemampuannya. Pemrosesan Informasi merujuk pada cara mengumpulkan / menerima stimuli dari lingkungan mengorganisasikan data, memecahkan masalah, menumukan konsep dan menggunakan symbol verval dan visual. Teori pemrosean infomasi / kognitif dipelopori oleh Robert Gagne (1985). Asumsinya adalah pembelajaran merupakan factor yang sangat penting dalam perkembangan.

Perkembangan merupakan hasil kumulatif dari pembelajaran. Dalam pembelajaran terjadi proses penerimaan informasi yang kemudian diolah sehingga menghasilkan output dalam bentuk hasil belajar. Dalam pemerosean informasi terjadi interaksi antara kondisi internal (keadaan individu, proses kognitif) dan kondisi-kondisi eksternal ( rangsangan dari lingkungan ) dan interaksi antar keduannya akan menghasilkan hasil belajar. Pembelajaran merupakan keluaran 
dari pemerosean informasi yang berupa kecapan manusia (human capitalities) yang terdiri dari : ( 1 ) informasi verbal ; (2) kecakapan intektual ; (3) strategi kognitif; ( 4 ) sikap; dan ( 5 ) kecakapan motoric.

Delapan fase protes pembelajaran menurut Robert M. Gagne adalah :

a. Motivasi, fase awal memulai pembelajaran dengan adanya dorongan untuk melakukan suatu tindakan dalam mencapai tujuan tertentu (motivasi intrinsic dan ekstrinik ).

b. Pemahaman, individu menerima dan memahami informasi yang diperoleh dari pembelajaran. Pemahaman didapat melalui perhatian.

c. Pemerolehan, individu memberikan makna / mepersepsi segala informasi yang sampai pada dirinya sehingga terjadi proses penyimpanan dalam memori siswa.

d. Penahanan, menahan informasi / hasil belajar agar dapat digunakan untuk jangka Panjang. Proses mengingat jangka Panjang.

e. Ingatlah kembali, mengeluarkan kembali informasi yang telah disimpan, bila ada rangsangan.

f. Generalisasi, menggunakan hasil pembelajaran untuk keperluan tertentu.

g. Perlakuan, perwujudan perubahan perilaku individu sebagai inti pembelajaran.

h. Umpan balik, individu memperoleh feedback dari perilaku yang telah dilakukannya.

Ada Sembilan langkah yang harus diperhatikan pendidik di kelas berkaitan dengan pembelajaran pemrosesan informasi.

a. Melakukan tindakan untuk menarik perhatian siswa.

b. Memberikan informasi mengenai tujuan pembelajaran dan topik yang akan di bahas.

c. Merangsang siswa untuk memulai aktivitas pembelajaran.

d. Menyampaikan isi pembelajaran sesuai dengan topik yang tidak direncanakan.

e. Memberikan bimbingan bagi aktivitas siswa dalam pembelajaran.

f. Memberikan feedback terhadap perilaku yang ditunjukan siswa

g. Memberikan penguatan pada perilaku pembelajaran. 
h. Melaksankan penilaian proses dan hasil.

i. Memberikan kesempatan kepada siswa untuk bertanya dan menjawab berdasarkan pengalamannya.

Model proses Informasi ini meliputi beberapa strategi pembelajaran di antaranya :

a. Mengajar induktif, yaitu mengembangkan kemampuan berpikir dan membentuk teori.

b. Latihan Inquiry, yaitu untuk mencari dan menentukan informasi yang memang diperlukan.

c. Inquiry Keilmuan, bertujuan untuk mengajarkan system penelitian dalam disiplin ilmu, dan diharapkan akan memperoleh pengalaman dalam domain domain disiplin ilmu lainnya.

d. Pembentukan konsep, bertujuan untuk mengembangkan kamampuan berpikir induktif, megembangkan konsep, dan kemampuan analisis.

e. Pengembangan, bertujuan untuk mengembangkan intelegensi umum, terutama berpikir logis, aspek social dan moral.

f. Advanced Organizer Model, bertujuan untuk mengembangkan kemampuan memproses informasi yang efesien untuk menyerap dan menghubungkan satuan ilmu pengetahuan secara bermana.

\begin{tabular}{|c|c|c|c|}
\hline $\mathrm{No}$ & Model & Tokoh & Tujuan \\
\hline 1 & $\begin{array}{l}\text { Model } \\
\text { berpikir } \\
\text { induktif }\end{array}$ & Hilda Taba & $\begin{array}{l}\text { Di rancang untuk pengembangan proses mental induktif } \\
\text { dan penalaran akademik / pembentukan teori. }\end{array}$ \\
\hline 2 & $\begin{array}{l}\text { Model } \\
\text { Latihan } \\
\text { inkuiri }\end{array}$ & $\begin{array}{l}\text { Richard } \\
\text { Suchman }\end{array}$ & $\begin{array}{l}\text { Pemecahan masalah social, terutama melalui penemuan } \\
\text { social dan penalaran logis. }\end{array}$ \\
\hline 3 & Inkuiri ilmiah & $\begin{array}{lll}\text { Joseph } & \text { J } \\
\text { Schwab } & \end{array}$ & $\begin{array}{l}\text { Di rancang untuk mengajar system penelitian dari suatu } \\
\text { disiplin, tetapi juga diharapkan untuk mempunyai efek } \\
\text { dalam Kawasan lain ( metode-metode social mungkin } \\
\text { diajarkan dalam upaya meningkatkan pemahaman social } \\
\text { dan pemecahan masalah social). }\end{array}$ \\
\hline 4 & $\begin{array}{l}\text { Penemuan } \\
\text { konsep }\end{array}$ & $\begin{array}{l}\text { Jerome } \\
\text { Brunner }\end{array}$ & $\begin{array}{l}\text { Di rancang terutama untuk mengembangkan penalaran } \\
\text { induktif, juga untuk perkembangan dan analisis konsep. }\end{array}$ \\
\hline
\end{tabular}




\begin{tabular}{|l|l|l|l|}
\hline 5 & $\begin{array}{l}\text { Pertumbuhan } \\
\text { kognitif }\end{array}$ & $\begin{array}{l}\text { Jean Piaget } \\
\text { Irving Sigel } \\
\text { Edmund } \\
\text { Sullvian } \\
\text { Lawrence } \\
\text { kohlberg }\end{array}$ & $\begin{array}{l}\text { Di rancang untuk memengaruhi siswa agar menemukan } \\
\text { nilai - nilia pribadi dan nilai - nilainya di harapkan anak } \\
\text { menjadi sumber bagi penemuan berikutnya. }\end{array}$ \\
\hline 6 & $\begin{array}{l}\text { Model penata } \\
\text { lanjutan }\end{array}$ & David Ausubel & $\begin{array}{l}\text { Di rancang untuk meningkatkan efisiensi kemampuan } \\
\text { pemerosesan informasi untuk menyerap dan mengaitkan } \\
\text { bidang - bidang pengetahuan. }\end{array}$ \\
\hline 7 & memori & $\begin{array}{l}\text { Harry Lorayne } \\
\text { \& Jerry Lucas }\end{array}$ & Di rancang untuk meningkatkan kemampuan mengingat. \\
\hline
\end{tabular}

\section{Model Personal (Personal Models )}

Model ini bertitik tolak dari teori Humanistik, yaitu berorientasi terhadap pengembangan dari individu.Perhatian utamanya pada emosional siswa untuk mengembangankan hubungan yang produktif dengan lingkungannya.Model ini menjadikan pribadi siswa untuk membentuk hubungan yang harmonis serta mampu memproses informasi secara efektif.

Model ini juga berorientasi pada individu pada individu dan perkembangan keakuan. Tokoh humanistic adalah Abraham Maslow ( 1962 ), R Rogers, C. Buhler, dan Arthur Comb. Menurut teori ini, agar siswa merasa bebas dalam belajar dan mengembangkan dirinya, baik emosional maupun intektual.Teori humanistic timbul sebagai gerakan memanusiakn manusia.Pada teori humanistic ini, pendidik seharusnya berperan sebagai pendorong bukan menahan sensitifitas siswa terhadap perasannya.

Implikasi teori humanistic dalam Pendidikan adalah sebagai berikut :

a. Bertingkah laku dan belajar adalah hasil pengamatan.

b. Tingkah laku yang ada, dapat dilaksanakan sekarang ( learning to do ).

c. Semua individu memiliki dorongan dasar terhadap aktualisasi diri.

d. Sebagian besar tingkah laku individu adalah hasil dari konsepsinya sendirinya.

e. Mengajar adalah hal penting, tapi belajar siswa adalah sangat penting (learn how to learn ). 
f. Mengajar adalah membantu siswa mengembangkan suatu hubungan yang produktif dengan lingkungannya dan memandang dirinya sebagai pribadi yang cakap.

Model pembelajaran personal ini meliputi strategi pembelajaran sebagai berikut :

a. Pembelajaran non - direktif bertujuan untuk membentuk kemampuan dan perkembangan pribadi ( kesadaran diri, pemahaman, dan konsep diri ).

b. Latihan kesadaran, bertujuan untuk meningkatkan kemampuan inter personal atau kepedulian siswa.

c. Sintesik, untuk meningkatkan kompleksitas dasar pribadi yang luwes.

\begin{tabular}{|l|l|l|l|}
\hline No & \multicolumn{1}{|c|}{ Model } & \multicolumn{1}{|c|}{ Tokoh } & \multicolumn{1}{c|}{ Tujuan } \\
\hline 1 & $\begin{array}{l}\text { Pengajaran } \\
\text { non } \\
\text { Direktif. }\end{array}$ & Carl Rogers & $\begin{array}{l}\text { Penekanan pada pembentukan kemampuan } \\
\text { untuk perkembangan pribadi dalam arti } \\
\text { kesadaran diri, pemahaman diri, kemandirian, } \\
\text { dan konsep diri. }\end{array}$ \\
\hline 2 & $\begin{array}{l}\text { Latihan } \\
\text { Kesadaran } \\
\text { William } \\
\text { Schultz }\end{array}$ & $\begin{array}{l}\text { Sinetik } \\
\text { eksplorasi diri dan kesadaran diri. Banyak } \\
\text { menekankan pada perkembangan kesadaran } \\
\text { dan pemahaman antar pribadi. }\end{array}$ \\
\hline 4 & $\begin{array}{l}\text { Sistem } \\
\text { system } \\
\text { Konseptual }\end{array}$ & David Hurt & $\begin{array}{l}\text { Dirancang dian Glaster } \\
\text { kekompleksan dan keluwesan pribadi. } \\
\text { pemecahan masalah kreatif. }\end{array}$ \\
\hline 5 & $\begin{array}{l}\text { Pertemuan } \\
\text { Kelas }\end{array}$ & Willian Glaster & $\begin{array}{l}\text { Perkembangan pemahaman diri dan } \\
\text { tanggung jawab kepada diri sendiri dan } \\
\text { kelompok social. }\end{array}$ \\
\hline
\end{tabular}

4. Model Modifikasi Tingkah laku (Behavioral)

Model ini bertitik tolak dari teori belajar behavioristic, yaitu bertujuan mengembangkan system yang efisien untuk megurutkan tugas-tugas belajar dan membentuk tingkah laku dengan cara memanipulasi penguatan ( reinforcement ). Model ini lebih menekankan pada aspek perubahan perilaku psikologis dan 
perilaku yamg tidak dapat diamati.Karakter model ini adalah dalam hal pembelajaran tugas-tugas yang harus dipelajari siswa lebih efisien dan berurutan.

Ada empat fase dalam model modifikasi tingkah laku ini yaitu :

a. Fase mesin pembelajaran ( $\mathrm{CAI}$ dan $\mathrm{CBI})$;

b. Penggunaan media ;

c. Pengajaran berprogram ( linear dan branching);

d. Operant conditioning dan operant reinforcement.

Implementasi dari model modifikasi tingkah laku ini adalah meningkatkan ketelitian pengucapan pada siswa, modifikasi tingkah laku anak yang kemampuan belajarnya rendah dengan memberikan reward, sebagai reinforcement pendukung, dan penerapan prinsip pembelajaran individu terhadap pembelajaran klasikal.

\begin{tabular}{|l|l|l|l|}
\hline No & \multicolumn{1}{|c|}{ Model } & \multicolumn{1}{|c|}{ Tokoh } & \multicolumn{1}{c|}{ Tujuan } \\
\hline 1 & $\begin{array}{l}\text { Manajemen } \\
\text { Kontingensi }\end{array}$ & B. F Skinner & Fakta - fakta, konsep keterampilan. \\
\hline 2 & Kontrol Diri & B. F Skinner & Perilaku / keterampilan social. \\
\hline 3 & $\begin{array}{l}\text { Relaksasi ( } \\
\text { santai })\end{array}$ & Rimm \& Masters & $\begin{array}{l}\text { Tujuan - tujuan pribadi ( mengurangi gangguan dan } \\
\text { kecemasan ). }\end{array}$ \\
\hline 4 & $\begin{array}{l}\text { Pengurangan } \\
\text { Ketegangan }\end{array}$ & Rimm \& Masters & $\begin{array}{l}\text { Mengalihkan kesantaian kepada kecemasan dalam } \\
\text { situasi social. }\end{array}$ \\
\hline 5 & $\begin{array}{l}\text { Latihan Asertif } \\
\text { Desensitasi }\end{array}$ & $\begin{array}{l}\text { Wolpe, Lazarus, } \\
\text { Salter }\end{array}$ & $\begin{array}{l}\text { Ekspresi perasaan secara langsung dan spontan dalam } \\
\text { situasi social. }\end{array}$ \\
\hline 6 & $\begin{array}{l}\text { Latihan } \\
\text { Langsung }\end{array}$ & $\begin{array}{l}\text { Gagne, Smith \& } \\
\text { Smith }\end{array}$ & Pola - pola perilaku, keterampilan. \\
\hline
\end{tabular}

\section{MACAM - MACAM MODEL DESAIN PEMBELAJARAN}

1. Model Pembelajaran Menurut Briggs

Model Pembelajaran Menurut Briggs berorientasi pada rancangan sistem dengan sasaran guru.Karena guru yang akan bekerja sebagai perancangan kegiatan instruksional dan yang akan menjadi tim pengembang instruksional. ${ }^{7}$

${ }^{7}$ Mudlofir, Ali., dan Rusydiyah Evi Fatimatur. Desain Pembelajaran Inovatif. Depok: PT

RajaGrafindo Persada. Prisansa, Donni Juni. 2016 
Langkah-langkah model pembelajaran Briggs (Prawiradilaga:2007), adalah:

a. Penentuan tujuan

Langkah awal ini merupakan langkah yang paling urgen,karena guru harus mengidentifikasi tujuan apa yang harus dicapai oleh peserta didik.

b. Perincian Tujuan

Tujuan yang telah di identifikasi di rinci berdasarkan keterampilanketerampilan apa yang akan dimiliki oleh peserta didik.

c. Rumusan tujuan

Tujuan yang telah di rinci tadi di rumuskan dalam satu kalimat pernyataan yang mengandung kemampuan apa dan tingkat kemampuan apa yang harus dimiliki oleh peserta didik selama mereka dalam proses pembelajaran.

d. Analisis tujuan

Kegiatan ini dilakukan agar tujuan-tujuan yang dianggap sering ditemukan tingkat kegagalannya diganti dengan tujuan-tujuan yang lebih rasional tingkat keberhasilannya.

e. Penyiapan evaluasi hasil belajar

Setelah melakukan hal-hal tersebut diatas langkah selanjutnya adalah menyiapkan evaluasi hasil belajar,kegiatan ini dilakukan berdasarkan tujuantujuan yang telah ditetapkan,oleh karena itu menyusun evaluasi belajar yang

2. Model pembelajaran Bella H.Banathy

Pengembangan system instruksional menurut Banathy dapat dibedakan dalam 6 (enam) langkah sebagai berikut (Banathy,1968) :

a. Langkah 1 : Merumuskan tujuan

Langkah pertama adalah merumuskan tujuan,yaitu suatu pernyataan pengalaman belajar yang menyatakan apa yang kita harapkan dari peserta didik untuk dikerjakan,diketahui,dan dirasakan sebagai hasil dari pengalaman belajarnya.

b. Langkah 2 : Mengembangkan tes (Developing test)

Dalam langkah ini dikembangkan suatu tes yang didasarkan pada tujuan yang diinginkan dan digunakan untuk mengetahui kemampuan yang diaharapkan dicapai sebagai hasil dari pengalaman belajarnya.

c. Langkah 3 : Menganalisis kegiatan belajar (Analyzing of learning task) 
Dalam langkah ini dirumuskan apa yang harus dipelajari sehingga dapat menunjukan tingkah laku seperti yang digambarkan dalam tujuan yang telah dirumuskan.Dalam kegiatan ini,kemampuan awal peserta didik harus juga di analisis atau di nilai,karena mereka tidak perlu mempelajari apa yang mereka telah ketahui atau kuasai.

d. Langkah 4 : Mendesain sistem Instruksional

Setelah itu perlu dipertimbangkan alternative-alternatif dan identifikasi apa yang harus dikerjakan untuk menjamin bahwa peserta didik akan menguasai kegatan-kegiatan yang telah di analisis pada langah ke 3 (functions analyze).Juga perlu ditentukan siapa atau apa yang mempunyai potensi yag paing baik untuk mencapai fungsi-fungsi tersebut harus dilaksanakan (component analyze).Perlu ditemtukan pula kapan dan dimana fungsi-fungsi tersebut harus dilaksanakan (design of system).

e. Langkah 5 : Melaksanakan kegiatan Mentes Hasil (implement and test output) Dalam langkan ini,sistem yang sudah di desain sekarang dapat diuji cobakan atau di tes dan dilaksanakan.Apa yang dapat dilaksanakan atau dikerjakan peserta didik sebagai hasil implementasi sistem harus nilai dapat di ketahui seberaba jauh mereka telah menunujukan tingkah laku seperti yang di maksudkan dalam rumusan tujuan.

f. Langkah 6 : Mengadakan Perbaikan

Hasil-hasil yang diperoleh dari evaluasi kemudian merupakan umpan balik untuk keseluruhan sistem,sehingga perubahan-perubahan,jika diperlukan dapat dilakukan untuk memperbaiki sistem instruksional. 
Langkah-langkah tersebut dapat dilihat dalam bagan berikut ini:

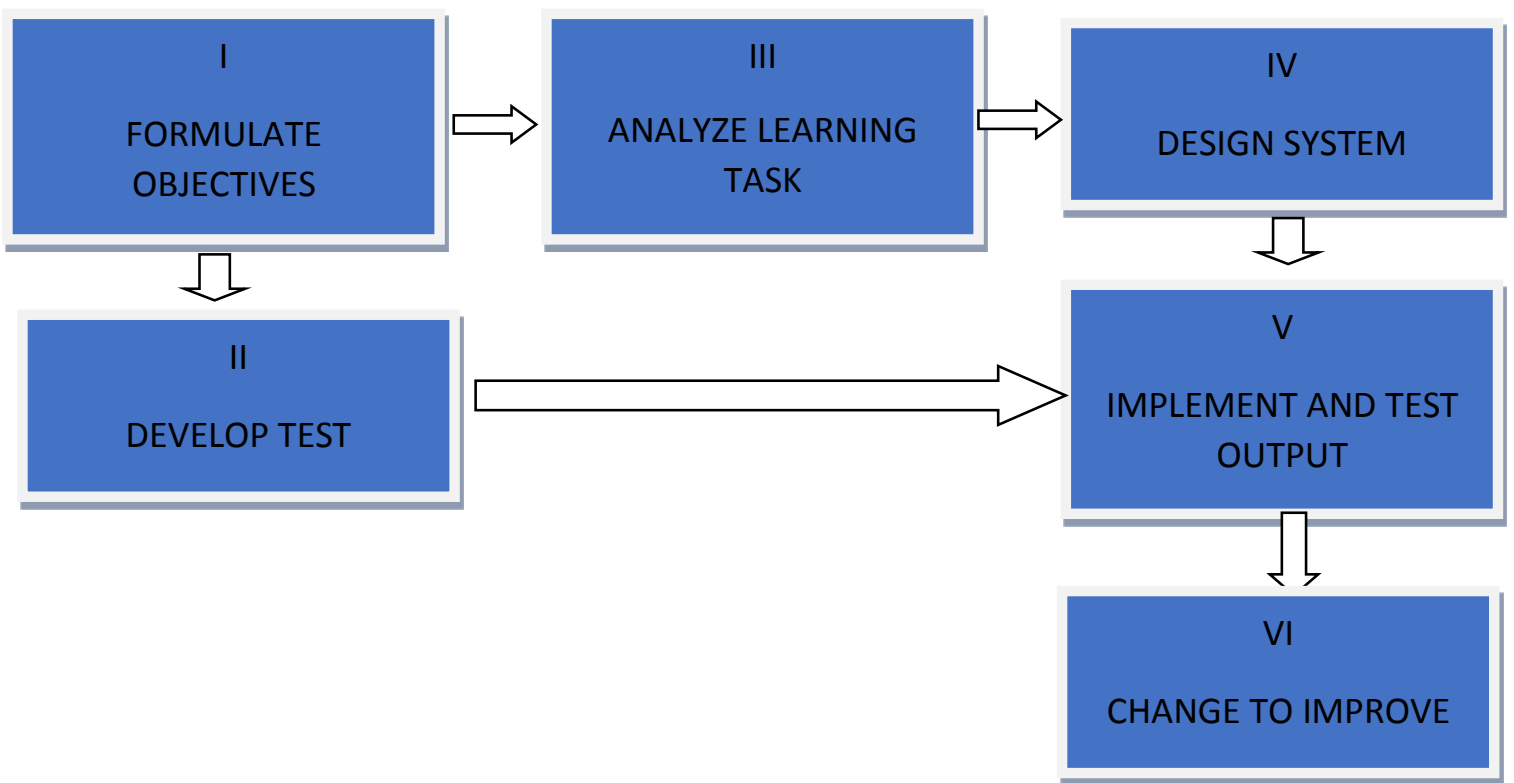

\section{Model Pembelajaran PPSI}

PPSI (Prosedur Pengembangan Sistem Instruksional) digunakan sebagai metode penyamapaian dalam rangka kurikulum 1975 untuk SD,SMP,dan SMA dan kurikulum 1976 untuk sekolah-sekolah kejuruan.PPSI menggunakan pendekatan yang berorientasipada tujuan.Istilah system instruksonal dalam PPSI menunjuk pada pengertian sebagai suatu sistem yaitu sebagai suatu kesatuan yang terorganisasikan yang terdiri atas sejumlah komponen yang saling berhubungan satu dengan yang lainnya untuk mencapai tujuan.Sebagai suatu sistem,pengajaran mengandung antara lain : materi,metode,alat,evaluasi,yang kesemuanya berinteraksi satu dengan yang lainnya untuk mencapai tujuan pangajaran yang telah dirumuskan.

Langkah-langkah pembelajaran PPSI ada kemiripan dengan langkah-langkah pembelajaran Banathy.'Terdapat lima langkah pokok dalam PPSI,yaitu:

a. Langkah 1: Merumuskan tujuan instruksional khusus

Tujuan instruksional khusus adalah rumusan yang jelas tentang kemampuan atau tingkah laku yang diharapkan dimiliki peserta didik setelah mengikuti suatu program pengajaran tertentu.Kemampuan-kemampuanatau tingkah 
laku tersebut harus dirumuskan secara spesifik dan operasional sehingga dapat diamati dan diukur.

b. Langkah 2 : Menyusun alat evaluasi

Setelah tujuan instruksional khusus dirumuskan,langkah selanjutnya adalah mengembangkan tes yang berfungsi untuk menilai sampai di mana peserta didik telah menguasai kemapuan-kemampuan yang telah dirumuskan dalam tujuan instruksional khusus di atas.Pengembangan alat evaluasi dirumuskan tidak dirumuskan pada akhir langkah,namun pada langkah yang kedu,hal ini didasarkan pada prinsip berorientasi pada tujuan atau hasil yang dicapai.Untuk mengukur apakah rumusan instruksional tersebut dapat dinilai apa tidak,perlu dikembangkan alat evaluasinya terlebih dahulu sebelum melangkah lebih jauh.Dengan dikembangkannya alat evaluasi pada langkah kedua ini,mungkin ada beberapa tujuan yang perlu diubah atau dipertegas rumusannya sehingga dapat diukur.

c. Langkah 3:Menentukan kegiatan belajar dan materipelajaran pada langkah ketiga ini,yang perlu dipertimbangkanadalah hal-hal sebagai berikut:

1) Merumuskan semua kemungkinan kegiatan belajar yang diperlukan untuk mencapai tujuan.

2) Menetapkan kegiatan yang tidak perlu ditempuh lagi oleh peserta didik.

3) Menetapkan kegiatan belajar yang masih perlu dilaksanakan oleh peserta didik setelah kegiatan-kegiatan belajar peserta didik ditentukan,perlu dirumuskan pokok-pokok materi pelajaran yang akan diberikan kepada peserta didik sesuai jenis-jenis kegiatan belajar yang telah ditetapkan.Bila dipandang perlu,setiap materi pelajaran tersebut dilengkapi dengan uraian singkat agar memudahkan guru atau dosen menyampaikan materi tersebut.

d. Langkah 4 : Merencanakan program kegiatan

Titik tolak merencanakan program kegiatan adalah satuan pelajaran yang diambil dari kurikulum yang telah tertentu jumlah jam pelajaannya dan diberikan pada kelas dalam semester tertentu.Pada langkah ini perlu disusun strategi proses pembelajaran dengan jalan merumuskan peranan dalam kegiatan mengajar dan kegiatan belajar yang disusun secara sistematis sesuai 
dengan keadaan dengan situasi kelas metode pengajaran akan digunakan dipilih yang paling sesuai untuk mencapai tujuan,termasuk dalam langkah ini adalah menyusun proses pelaksanaan evaluasi.

e. Langkah 5 : Melaksanakan program

Langkah-langkah yang dilakukan dalam fase ini adalah;

1) Mengadakan pre-test

Tujuan pretest diberikan adalah untuk mengukur kemamuan awal peserta didik yang sesuai dengan tujuan instruksional khusus sebelum mereka mengikuti pengajaran.Apabila peserta didik telah menguasai kemampuan yang tercantumdalam tujuan instruksional yang ingin dicapai,maka hal itu tidak perlu diberikan lagi dalam program pengajaran yang akan diberikan.

2) Menyampaikan materi ajar

Penyampaian materi harus berpegang pada langkah yang ke-4 yatu merencanakan program.Pada langkah ini adalah tindakan dari rencana tersebut,oleh karena itu guru harus siap dalam materi,metode,dan alat atau media yang digunakan dalam kelas.Demikian juga pada awal pertemuan guru harus menyampaikan tujuan yang akan dicapai pada pertemuan tersebut.

3) Mengadakan evaluasi (post-test)

Pemberian post-test dimaksudkan untuk mengukur kemampuan peserta didik setelah materi diberikan,dengan demikian dapat diketahui seberapa jauh program pengajaran telah berhasil diberikan

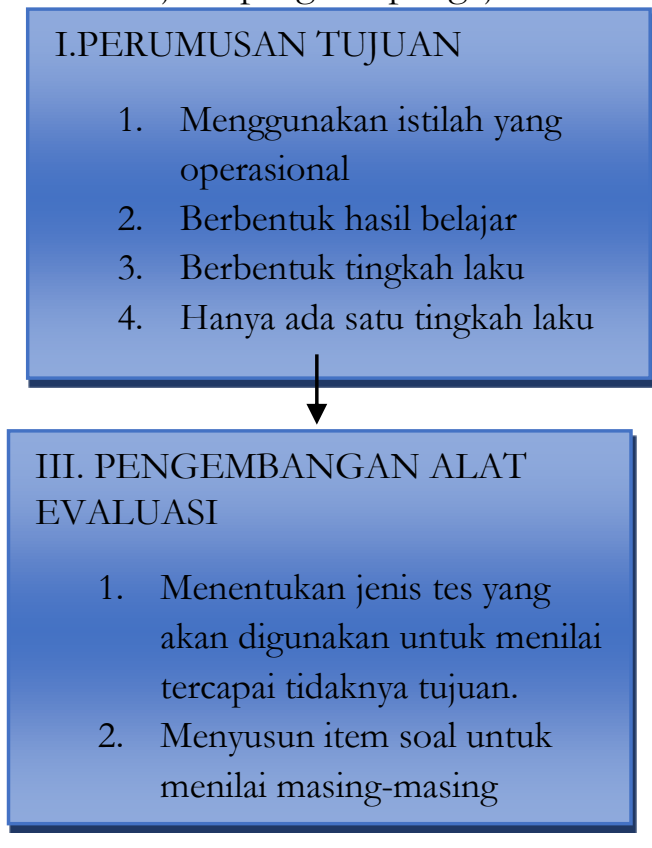

Volume 4, Nomor 1, Maret 2020
II. KEGIATAN BELAJAR

1. Menggunakan istilah yang operasional

2. Berbentuk hasil belajar

3. Berbentuk tingkah laku

4. Hanya ada satu tingkah laku

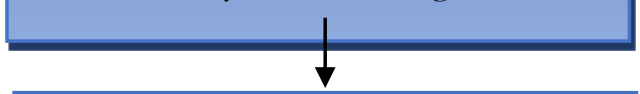

IV. PENGEMBANGAN PROGRAM KEGIATAN

1. Merumuskan materi

2. Menetapkan metode yang dipakai

3. Memilih alat pelajaran dan sumber yang dipakai

4. Menvusun iadwal 
4. Model IDI

Model IDI (Instruction Develoment Intitute) diekmbangkan oleh University Consortium for Instructional Develoment and Technology (UCDIT).Konsorsium tersebut terdiri dari University of Southers California (USC),Internasional University di san Diego,Michigan State University (MSU),Syracuse University,dan Indiana University.Model ini pada prinsipnya terdiri mempunyai tiga tahapan,yaitu: define, develop, dan evaluate.

a. Tahap Pemabatasan (Define)

Tahap ini terdiri dari:

1) Identikasi Masalah

Identifikasi masalah dimulai dengan:

a. Need assesment

Langkah ini bertujuan untuk memenuhi harapak kebutuhan pesserta didik,keluarganya,dan masyarakat melalui jalur pendidikan.Need assessment juga berfungsi untuk menemukan perbedaan antara keadaan sekarang dan apa yang diinginkan secara ideal.

Perbedaan tersebut menyebabkan adanya kebutuhan untuk menyelesaikan masalah.Hali ini berarti timbul masalah.Bila perbedaan dapat ditemukan,tujuan pemecahan masalah dapat kkita carikan.

b. Establish Priorities

Langkah ini adalah bertujuan untuk memilah dan memilih problem apa yang segera diselesaikan masalahnya.Karena dalam setiap institusi memiliki beraneka ragam problem,maka setiap sekolah harus memiliki problem mana yang harus di prioritaskan dan tidak.

c. State Problem

Langkah ini merupakan akhir dari identifikasi problem.Setelah pengembang mengadakan analisis kebutuhan dan menegakan problem,maka pengembangan harus dapar merumuskan problem apa yang akan diselesaikan masalahnya. 
Ketiga langkah dalam identifikasi problem tersebut dapat digambarkan dalam bagan berkut:

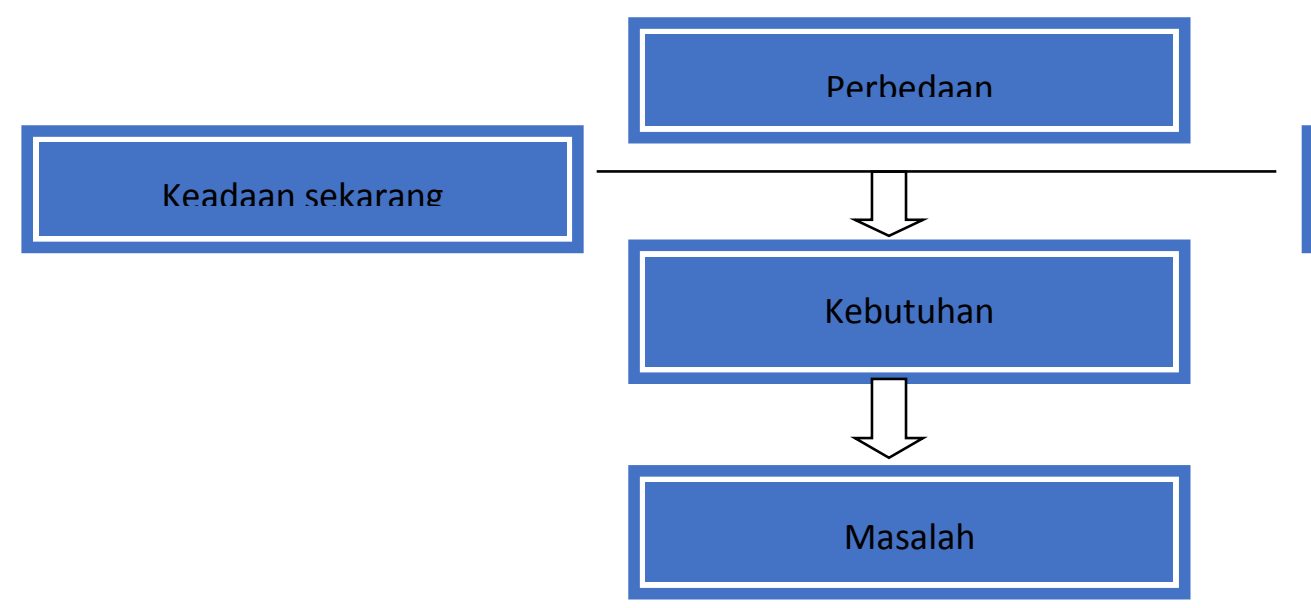

2) Analisis latar (Analyze Setting)

Ada tiga hal yang perlu di perhitungkan pada langkah kedua yaitu:

a) Karakteristik peserta didik

Kegiatan instruksional hendaknya berorientasi pada peserta didik.Peserta didik tidak lagi dipandang sebagai objek yang bersifat pasif dan dapat diperlukan sewenang-wenang oleh guru,tetapi sebagai subjek dan mempunyai cirri dan karakteristik.

Tujuan uji coba ini adalah mengumpulkan data tentang kebaikan atau kelemahan dan efisiensi atau efektifitas program yang sudah tersusun.

b) Analisi Hasil

Hasil uji coba perlu dianalisis, di mana ada tiga hal yang perlu diperhatikan

- Apakah tujuan dapat tercapai?bila tidak,di manakah kesalahnnya?sudah tepatkah rumusannya?

- Apakah metode yang dipakai sudah cocok untuk mencapai tujuan-tujuan tersebut mengingat karakteristik peserta didik seperti yang telah diiedentifikasikan?

- Apakah tidak ada kesalahan dalam pembuatan instrument evaluasi?apakah sudah dievaluasi hal-hal yang seharusnya perlu dievaluasi. 
3) Pelaksanaan

Bila dari analisis tersebut ternyata menunjukan tujuan sudah dapat dicapai,teknik yang dipakai sudah sesuai untuk mencapai tujuan yang dirumuskan dan tidak terjadi kesalahan maka dapat dilaksankan implementasi.Tetapi apabila terjadi masih ada kesalahan dalam merumuskan tujuan,atau kesalahan dalam teknik penyajian untuk mencapai tujuan maka perlu diadakan revisi.

Beberapa langkah model desain pembelajaran menurut IDI dapat digambarkan sebagai berikut:

\begin{tabular}{|l|l|l|}
\hline IDENTIFY & ANALYZE & ORGANIZE \\
PROBLEM & SETTING & MANAGEMENT \\
\hline Asses needs & Audience & Task \\
Establish & Conditions & Responsibility \\
priority & Relevant & Time lines \\
State problem & Resources & \\
\hline
\end{tabular}

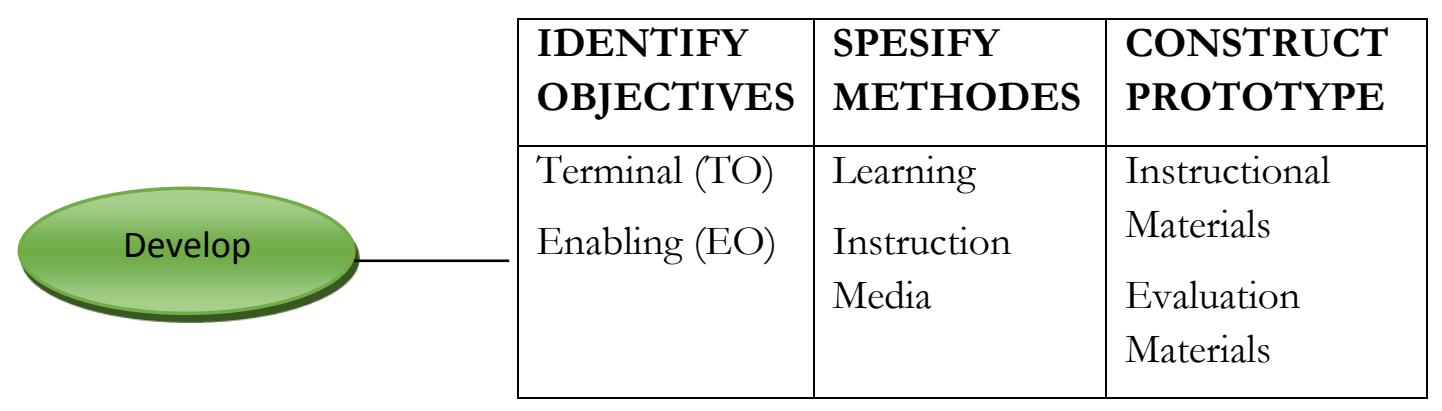

\begin{tabular}{|c|c|c|c|}
\hline \multirow{4}{*}{ Evaluate } & $\begin{array}{ll}\text { TEST } & \text { TRY } \\
\text { OUT } & \end{array}$ & $\begin{array}{l}\text { ANALYZE } \\
\text { RESULTS }\end{array}$ & $\begin{array}{l}\text { IMPLEME } \\
\text { NT/RECY } \\
\text { CLE }\end{array}$ \\
\hline & \multirow{3}{*}{$\begin{array}{l}\text { Conduct try out } \\
\text { Collect } \\
\text { Evaluation } \\
\text { Data }\end{array}$} & Objectives & \multirow{3}{*}{$\begin{array}{l}\text { Review } \\
\text { Decide } \\
\text { Act }\end{array}$} \\
\hline & & Methodes & \\
\hline & & $\begin{array}{l}\text { Evaluation } \\
\text { Techniques }\end{array}$ & \\
\hline
\end{tabular}

5. Model Pembelajaran Kemp

Model pengembangan instruksional menurut Kemp (1977) atau yang disebut rancangan instrusional,terdiri dari delapan langah,yaitu: 
a. Langkah pertama: Menentukan tujuan umum (kurikulum1994 disebut TIU,kurikulum 2004 dan 2006 disebut dengan dalam kurikulum2013 disebut dengan kompetensi inti dan kompetensi dasar).Tujuan umum ini adalah tujuan yang ingin dicapai dalam memfasilitasi pada masing-masing pokok bahasan.

b. Langkah kedua : membuat analisi tentang karakteristik peserta didik.Analisis ini diperlukan antara lain untuk mengetahui pakah latar belakang pendidikan,dan sosial budaya peserta didik memungkinkan untuk mengikuti program dan langkah-langkah apa yang perlu diambil.

c. Langkah ketiga: Menentukan kompetensi dan indicator yang operasional dan terukur.Dengan demikian peserta didik akan tau apa yang harus dikerjakan,bagaimana mengerjakannya dan apa ukurannya bahwa dia telah berhasil.Dari segi pembelajar rumusan itu akan berguna dalam menyusun tes kemampuan atau keberhasilan,dan pemilihan materi yang sesuai.

d. Langkah keempat: Menentukan materi/bahan pelajaran yang sesuai dengan indicator

e. Langkah kelima: Mnetapkan tes awal (pre-test) ini di perlukan untuk mengetahui sejauh mana peserta didik telah memenuhi prasyarat belajar yang dituntut untuk mengikuti program yang bersangkutan.Dan demikian pembelajar dapat memilih materi yang diperlukan tanpa harus menyajikan yang tidak perlu.

f. Langkah keenam: Menentukan strategi belajar mengajar yang sesuai criteria umum untuk pemilihan strategi belajar mengajar yang sesuai dengan tujuan instruksional kekhusus tersebut adalah: (a) efisiensi, (b) efektifitas, (c) ekonomis dan (d) kepraktisan,melalui analisis alternative.

g. Langkah ketujuh: Mengoordinasi sarana penunjangn yang diperlukan,meliputi biaya,fasilitas,peralatan,waktu dan tenaga.

h. Langkah kedelapan: Mengadakan evaluasi.Evaluasi ini sangat diperlukan untuk mengontrol dan mengkaji keberhasilan program secara keseluruhan,yaitu: pesera didik,program instruksional,instrument evaluasi atau tes,dan metode. 
Dalam diagram,bentuk desain instruksional Kemp tersebut dapat digambarkan sebagai berikut:

1. Menentukan tujuan

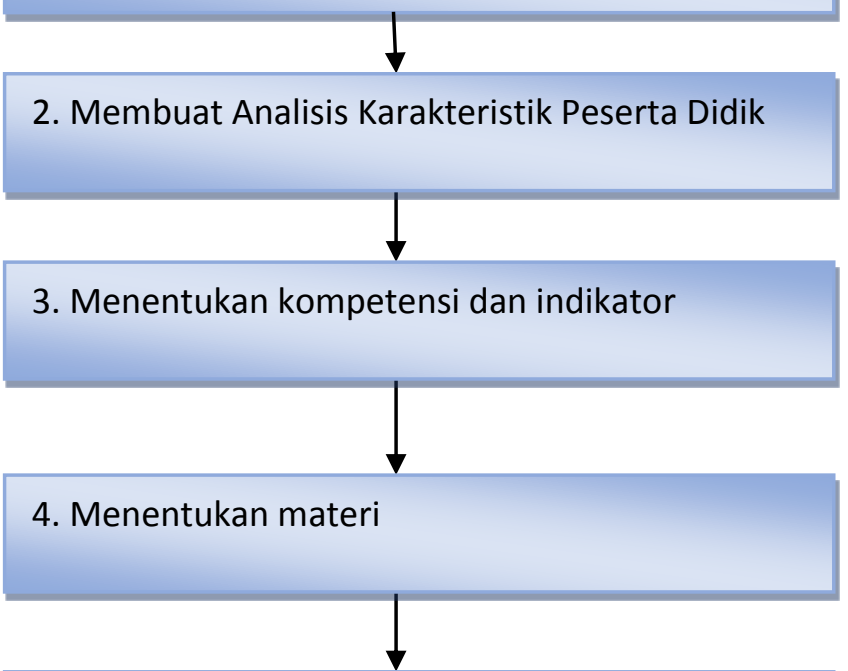

5. Menetapkan tes awal/Pre-test

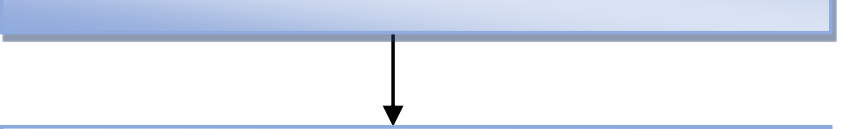

6. Menentukan strategi belajar yang sesuai

8. Melakukan evaluasi/Post-test

7. Mengoordinasikan sarana penunjang 
6. Model pembelajaran Dick and Carey

Dengan menggunakan kerangka berpikir sistem,Dick \& Carey $(1978,1985)$ menyusun model desain instruksional seperti berikut:

a. Mengidentifikasi tujuan pembelajaran

Mengidentifikasi tujuan pembelajaran adalah menentukan apa yang dihendaki oleh guru agar dapat dilakukan oleh peserta didik selesai mereka mengikuti pembelajaran.Batasan tujuan dapat dilihat dari standar kompetensi,kebutuhan kurikulum,kesulitan belajar,karakteristik peserta didik,dan lain-lain.

b. Melakukan analisis pembelajaran

Setelah mengetahui tujuan pembelajaran,guru hendaknya menentukan jenis pembelajaran yang bagaimana yang dikehendaki oleh peserta didik.Tujuan pembelajaran perlu dianalisis untuk mengenali keterampilan-keterampilan bawahan atau subordinat yang mengaharuskan peserta didik bawahan atau subordinat yang mengharuskan peserta didik menguasai materi dan langkahlangkah procedural bawahan yang ada yang diikuti peserta didik untuk mengikuti proses pembelajaran tertentu,

c. Mengidentifikasi perilaku awal dan karakteristik

Disamping mengenal keterampilan-keterampilan bawahan dan langkah-langkah procedural yang harus dimasukan ke dalam pembelajaran,maka perlu untuk mengenali keterampilan tertentu yang harus dimiliki peserta didik sebelum pembelajaran dimulai.Hal ini bukan berarti menyusun daftar semua hal yang dapat dilakukan oleh peserta didik,melainkan mengenali keterampilanketerampilan tertentu yang harus dimiliki peserta didik untuk memulai pembelajaran.

d. Merumuskan tujuan pembelajaran

Atas dasar analisis pembelajaran dan keterangan tentang tingkah laku masukan,pembelajar menyusun pernyataam spesifik tentang keterampilan apa yang akan dimiliki oleh peserta didik ketika telah menyelesaikan proses pembelajaran pernyataan yang dijabarkan dari keterampilan-keterampilan yang dikenali dengan jalan melakukan analisis pembelajaran ini perlu menyebutkan keterampilan-keterampilan yang harus dimiliki oleh peserta didik,kondisi 
perbuatan yang menunjukan keterampilan tersebut,dan criteria perfomanci yang berhasil.

e. Mengembangkan butir tes acuab criteria

Berdasarkan tujuan khusus atau kompetensi dasar yang telah dirumuskan,guru menyusun butir-butir penilaian yang sejajar yang dapat mengukur kemampuan peserta didik untuk mencapai apa yang dicantumkan dalam kompetensi dasar atau tujuan pembelajaran.Tekanan utama diletakan pada mengaitkan pada jenis tingkah laku yang disebutkan dalam tujuan dengan apa yang diminta daro butir-butir tersebut.

f. Mengembangkan strategi pembelajarn

Dengan adanya keterangan-keterangan dari langkah-langkah sebelumnya,guru harus memulai strategi yang akan digunakan dalam pembelajaran dan menentukan media apa yang cocok untuk dapat digunakan dalam mencapai tujuab akhir.Bagian-bagian strategi pembelajaran dapat dilihat dari kegiatan prapembelajaran,inti,dan penutup.

g. Mengembangkan dan memilih bahan pembelajaran

Langah ini didasarkan atas strategi prmbelajaran,kegiatan mengembangkan dan memilih bahan pembelajaran meliputi buku petunjuk peserta didik,bahan ajar,tes, dan buku pegangan guru.Keputusan untuk mengembangkan bahan ajar pada dasarnya tergantung pada jenis pembelajaran yang dilakukan.

h. Merancang dan melakukan evaluasi formatif

Kegiatan ini adalah melakukan serangkaian penilaian dengan maksud mengumpulkan data yang digunakan untuk mengidentifikasi bagaimana teknikteknik dalam menyempurnakan rencana pembelajaran.

i. Merevisi pembelajaran

Data dari penilaian formatif dianalisis sebagai usaha untuk mengenali kesulitankesulitan tersebut dengan kekurangan tertentu dalam proses pembelajaran.

j. Melakukan evaluasi sumatif

Langkah ini mempunyai arti mengadakan tindakan penilaian secara keseluruhan yang dimulai dari pertemuan pertama sampai yang terakhir,oleh karena itu idealnya penilaian ini tidak hanya melibatkan guru,namu juga tim evaluator yang indepeden. 


\section{KESIMPULAN}

Pembelajaran pada hakikatnya merupakan suatu proses interaksi antara guru dan siswa, baik interaksi secara langsung seperti kegiatan tatap muka maupun secara tidak langsung, yaitu dengan menggunakan berbagai media. Model pembelajaran adalah suatu rencana atau pola yang dapat digunakan untuk membentuk kurikulum ( rencana pembelajaran), sehingga kegiatan belajar mengajar lebih baik. Dengan menggunakan model pembelajaran dengan baik maka kita akan tau model yang telah didesain oleh guru yang diterapkan ke siswa maka, kita akan tahu sifat siswa dapat diketahui kekurangan dan kelebihan model yang telah di desain oleh guru. Karena Smaldino ( 2005 ) berpendapat bahwa guru yang mendesain model pembelajaran harus juga mempertimbangkan peserta didik, karena mereka mempunyai karakteristik yang berbeda - beda.

\section{DAFTAR PUSTAKA}

Jamaluddin, Dindin. 2010. Metode Pendidikan Anak. Bandung: Pustaka Al-Fikriis.

Jurnal Saintech Vol. 08 - No.04-Desember 2016.

Mudlofir, Ali., dan Rusydiyah Evi Fatimatur. Desain Pembelajaran Inovatif. Depok: PT RajaGrafindo Persada.

Prisansa, Donni Juni. 2016. Pengembangan Strategi Dan Model Pembelajaran.Bandung : CV Pustaka Setia.

Rusman. 2010. Model-model Pembelajaran. Jakarta: PT RajaGrafindo Persada.

Syah, Muhibbin. 2010. Psikologis Pendidikan. Bandung : PT Remaja Rosdakarya. 